\title{
Trends of Abundance of Salton Sea Fish: A Reversible Collapse or a Permanent Condition?
}

\author{
Ralf Riedel1,2 \\ ${ }^{1}$ Gulf Coast Research Laboratory, College of Marine Sciences, University of Southern Mississippi, Ocean Springs, MS, USA \\ ${ }^{2}$ Present Address: S\&R Consultancy, Ocean Springs, MS, USA \\ Email: ralf.riedel@usm.edu
}

How to cite this paper: Riedel, R. (2016) Trends of Abundance of Salton Sea Fish: A Reversible Collapse or a Permanent Condition? Natural Resources, 7, 535-543. http://dx.doi.org/10.4236/nr.2016.710045

Received: September 21, 2016

Accepted: October 23, 2016

Published: October 26, 2016

Copyright $\odot 2016$ by author and Scientific Research Publishing Inc. This work is licensed under the Creative Commons Attribution International License (CC BY 4.0).

http://creativecommons.org/licenses/by/4.0/

\begin{abstract}
The Salton Sea is a closed-basin, $980 \mathrm{~km}^{2}$ salt lake in the Sonoran Desert of southern California. Three marine species, bairdiella (Bairdiella icistia), orangemouth corvina (Cynoscion xanthulus), and sargo (Anisotremus davidsoni), established from introductions of over 34 species beginning in 1929. During the late 1960s and early 1970s, a hybrid tilapia (Oreochromis mossambicus $\times$ O. urolepis hornorum) invaded the Salton Sea and became dominant by number and weight. Recent surveys show a precipitous decline of all four species above starting sometime between 2001 and 2002. Declines were more evident in nearshore than in estuarine habitats. Corvina has probably declined the soonest, followed by Gulf croaker. Tilapia declines were followed by more recent increases in population numbers. The tilapia rebound observed are probably only sustainable if a curb in Salton Sea salinity levels is realized. The marine species will likely need restocking to reach historic levels, if the salinity of the lake is managed at $40 \mathrm{~g} \cdot \mathrm{L}^{-1}$ or below. Restoration alternatives for the Salton Sea must take into consideration estuarine areas as essential fish habitats and fish refuge against high salinities.
\end{abstract}

\section{Keywords}

Tilapia, Sciaenidae, Salt Lakes, Fisheries Collapse, Restoration, Salinity

\section{Introduction}

The Salton Sea is a $980 \mathrm{~km}^{2}$, closed basin salt lake in the Sonoran Desert of southeastern California (Figure 1). The lake is sustained by nutrient rich agriculture wastewater inflows, primarily from the Alamo and New Rivers. The salinity of the lake is currently hypersaline, with salinity rising at $0.5 \mathrm{~g} \cdot \mathrm{L}^{-1} \cdot \mathrm{y}^{-1}$ [1] [2]. The Salton Sea experiences wind-driven episodic deoxygenation events over most of its pelagic area during the hot 


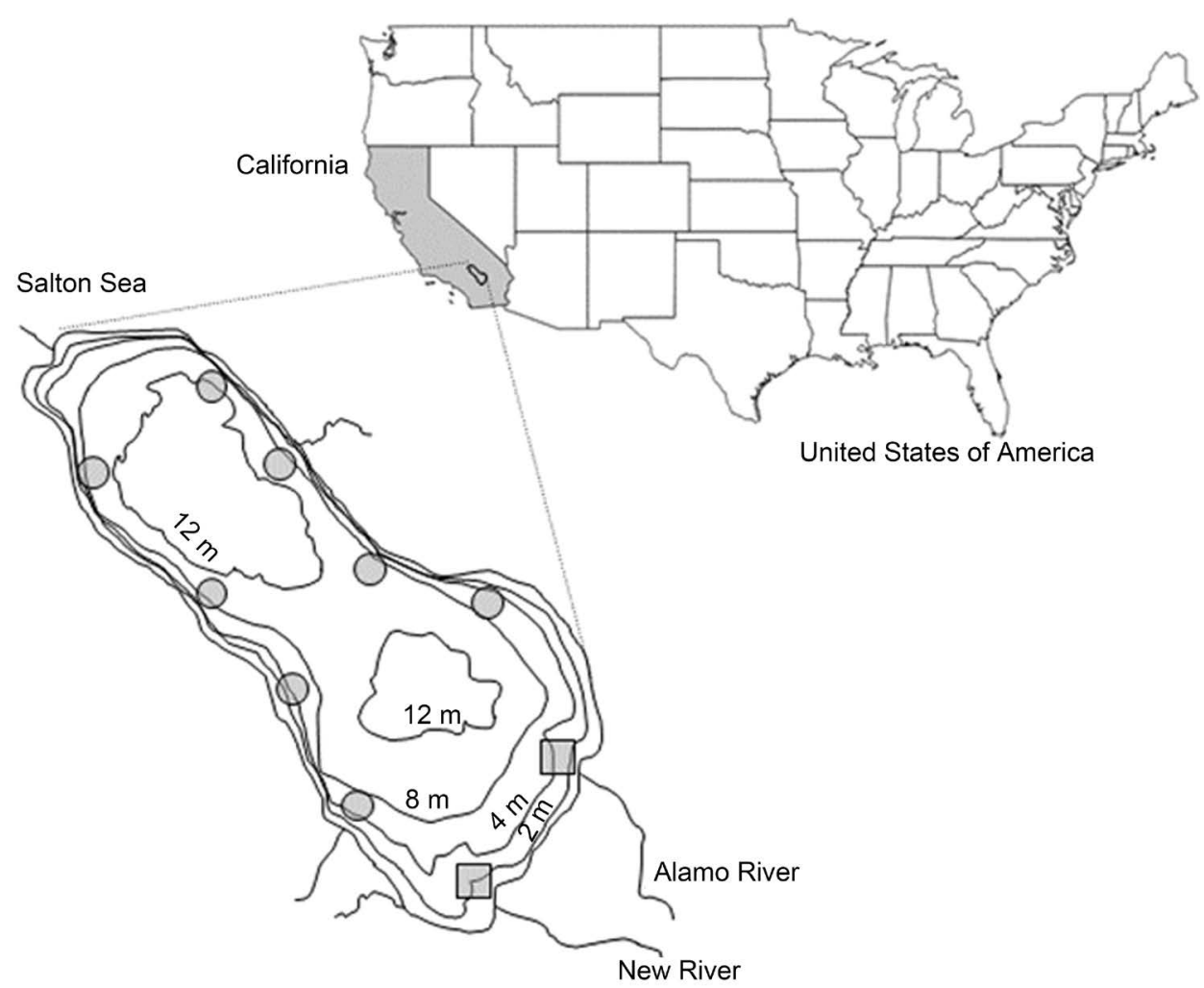

Figure 1. Salton Sea fish sampling locations during the $1999 / 2000$ and $2003 / 2008$ periods; circles indicate nearshore stations and squares are estuarine stations.

summer months, when water temperatures may reach $32 \mathrm{C}$ [3], causing massive fish and bird die offs [4]-[9]. The high nutrient inputs cause dense algal blooms, which further exacerbate dissolved oxygen limitations [10]. The extreme environment at the Salton Sea have caused behavioral adaptations in fish, such as dissolved oxygen- and temperature-driven movement patterns, and are possibly causing physiological adaptations due to isolation of the lake and the highly stressful and unpredictable environment.

The Salton Sea is located in the Salton Sink, the location of the ancient, freshwater Lake Cahuilla during the Pleistocene period [11] [12] [13]. In historical times, intermittent flows of the Colorado River filled the Salton Sink over periods as short as a few decades, followed by evaporation to a dry, alkaline lake bed [11]. The modern Salton Sea was formed in 1905 after a flood broke through irrigation headworks. Water flowed unabated into the Salton Sink until 1907, forming what is now the largest lake in California [14]. Many of the original freshwater species disappeared by 1929 [15]. Freshwater fish species still occur in the drainages and incoming tributaries of the Salton Sea [16]. Between 1950 and 1956, California fisheries officials introduced over 30 marine species from the northern Gulf of California in an attempt to develop a sport fishery, of which only the Gulf croaker (Bairdiella icistius Jordan \& Gilbert), orangemouth corvina (Cynoscion xanthulus Jordan \& Gilbert), and sargo (Anisotremus davidsoni Steindachner) established [14]. The redbelly tilapia (Tilapia zilli) was also introduced in the 1960s to control incidence of mosquitos [17]. Redbelly tilapia occurred in both, the tri- 
butaries and the Salton Sea proper. In the late 1960s and early 1970s, a hybrid tilapia (Oreochromis mossambicus Linnaeus $\times O$. urolepis hornorum Linnaeus) invaded the Salton Sea [18] and became the dominant fish by number and weight [19] [20] [21]. Redbelly and Mozambique tilapia remain discrete population now.

Recent events linked to salinity, dissolved oxygen, and sulphide concentrations have been blamed for massive fish dieoffs and consequent demise of the fish populations in the lake, a critical resource for local tourism and many migratory birds. I report results from data since 1999 documenting the declines in abundance of the three most common fish species and assess fish body condition in response to the deteriorating environment for Salton Sea fish.

\section{Methods}

During 1999 and 2000 Salton Sea fish were sampled with multipanel gill nets at rivers (1999 only), nearshore, pelagic, and estuarine areas [20]. Multipanel gill nets were chosen to enable sampling of all fish sizes present [22] [23] [24]. Gill nets consisted of five $10 \mathrm{~m}$ long $\times 2 \mathrm{~m}$ deep twisted nylon panels of $1,2,7,10$, and $12.5 \mathrm{~cm}$ stretched mesh sizes. Fish were weighed to the nearest gram and total length measured to the nearest millimeter. Catch-per-unit-effort (CPUE) was the ratio between the number of fish of a same species sampled in a gillnet and gillnet soaking time (fish/hour). Each net yielded one catch-per-unit-effort value per species.

In the spring of 2003 the California Department of Fish and Game (CDFG) started quarterly sampling at 14 stations at the Salton Sea as part of a long term monitoring program lasting through 2008. Sampling comprised all habitat types as above, except for rivers. Sampling was during April and May, July and August, October and November (2003), and January-April, July and August, October-December (2004); January and February, April and May, July and August, October and November (2005), January and February, April-May, July, October and November (2006), February-May, July and August, and October (2007), April-May, July and August, and October (2008). Sampling gear followed Riedel et al. [20]. Two nets were set in 2.5 to $4.5 \mathrm{~m}$ of water, typically 200 to 300 meters from shore. During CDFG samplings, fish were counted and net soaking times recorded.

Comparisons of CPUEs were made in this study among the years 1999, 2000, 2003-2008 by sampling area to show the magnitude of change in fish abundance with time. Only the most common species during the span of data were considered, namely Gulf croaker, corvina and tilapia. Sargo was a common species during 1999 and 2000, but was omitted from analyses because it disappeared sometime between 2000 and 2003. Each species was analyzed independently. Only nearshore and estuarine areas were analyzed (Figure 1) because they were the only habitat consistently sampled by CDFG.

Catch-per-unit-effort was logarithm transformed prior to analyses because of data heteroschedasticity. To avoid undefined values following transformation, a constant of 0.04 was added to each CPUE datum. The constant represented the smallest CPUE value obtainable from our sampling effort, namely one fish divided by the largest soaking time (25.0 hours). Differences in CPUE by species were assessed using a 2-way analy- 
sis-of-variance (AOV). We used sampling area and year as factors. Sampling area levels were nearshore and estuarine, and year levels were all years where sampling occurred (1999, 2000, and 2003-08).

\section{Results}

Tilapia declined markedly from 1999 to 2003 ( $\mathrm{p}<0.01$ for factor year, 516 error degrees of freedom), but increased from 2003 to 2008 (Figure 2). Factor habitat was marginally significant $(\mathrm{p}=0.063)$. Tilapia mean CPUE by year was $9.2 \pm 1.66$ standard error of the mean (SEM) in 1999, $19.4 \pm 7.03$ SEM in 2000, $0.8 \pm 0.32$ SEM in 2003, $1.5 \pm 0.46$ SEM in 2004, $2.5 \pm 0.57 \mathrm{SEM}$ in 2005, 8.9 $\pm 1.54 \mathrm{SEM}$ in 2006, $14.6 \pm 3.15 \mathrm{SEM}$ in 2007, and $20.3 \pm 1.88$ SEM in 2008. Estuarine areas produced more tilapia than nearshore areas $(11.2 \pm 3.03$ vs. $6.6 \pm 0.62 \mathrm{SEM})$.

Gulf croaker and corvina showed a decline since 1999, but did not show an increase from 2003 to 2008 (Figure 2). Nearshore areas produced more Gulf croaker than estuarine areas. Gulf croaker mean CPUE in the nearshore during the 1999 period was3.1 $\pm 0.60 \mathrm{SEM}$, during 2000 was $10.2 \pm 3.90 \mathrm{SEM}$, and during 2003 was $0.06 \pm 0.039$

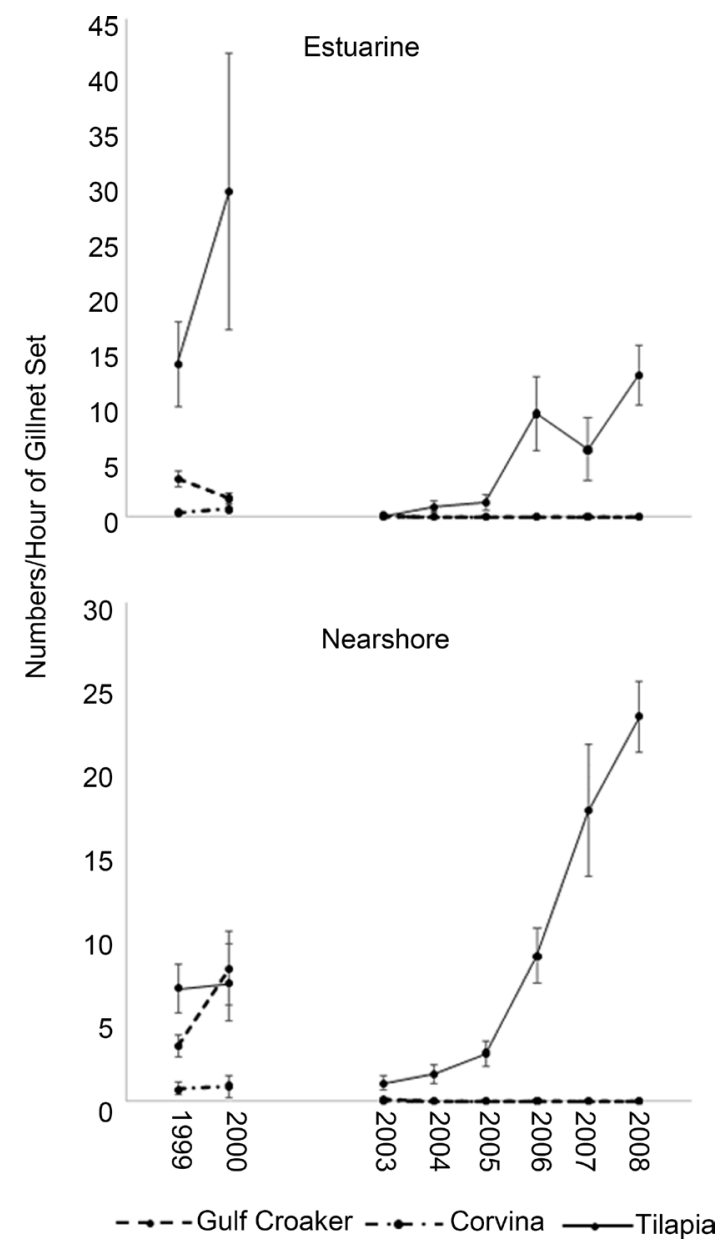

Figure 2. Number \pm standard error of the mean of Salton Sea fish sampled in the 1999/2000 and the 2003/2008 periods at estuarine and nearshore habitats. 
SEM. Gulf croaker mean CPUE in the estuarine area during the 1999 period was $2.6 \pm$ 0.66 SEM, during 2000 was $2.2 \pm 0.83$ SEM, and during 2003 was $0.04 \pm 0.021$ SEM. No Gulf croaker was sampled after 2004.

Corvina mean CPUE was higher in the estuarine area only during 2000. Mean CPUE in the estuarine area during 1999 was $0.4 \pm 0.19$ SEM and during 2000 was $1.4 \pm 0.38$ SEM. No corvina were sampled in the estuarine area after 2000. Mean CPUE in the nearshore area during 1999 was $0.4 \pm 0.13$ SEM, during 2000 was $0.7 \pm 0.23$ SEM, and during 2003 was less than 0.01 . No corvina were sampled in the nearshore area after 2004.

\section{Discussion}

The data show Salton Sea Gulf croaker and corvina collapsing sometime after 2000 and tilapia substantially declining by 2003 , but starting to recover at later years. I also show that the corvina body condition was lower during the years of low tilapia abundance, indicating that corvina may directly depend on tilapia. No such decline in body condition was observed for Gulf croaker.

All species were similarly affected by water quality in the summer and tilapia is likely the most affected by the low temperatures in the winter. I feel that reproductive failures for the Gulf croaker, corvina, and sargo were responsible for their collapse. Those species are broadcast spawners, which do not offer any parental care to eggs and young. Eggs and early fish were, thus, much more vulnerable to the adverse Salton Sea environment. Tilapia, on the other hand, are mouthbrooders, which might have accounted for the persistence to date of that species in the Salton Sea. A better ability to explore food resources and to cope with predation might also have been causes contributing to the survival of tilapia. Another factor contributing for tilapia survival is their choice of habitat during early-life. Tilapia occur close to shore during their early life, which is a more aerated habitat and less subject to the extreme variation in dissolved oxygen during warm months.

Factors influencing fish reproduction include salinity and temperature, both of which may be at or even above stressful levels for Salton Sea fish. Adult fish are also subject to episodic, wind-generated upwelling, which cause oxygen-poor, sulfide-rich waters to span the entire water column [2]. This may cause extensive mortality of adult fish, which are already at low reproductive success at the Salton Sea. This was most likely an important factor for the declines observed at the Salton Sea.

In addition to water quality factors, massive infestations from parasites might also have added to the high fish mortality rates, especially tilapia [25] [26] [27]. Gulf croaker was the species that declined the slowest, possibly because of its better ability to feed on pile worms (Neanthes succinea) and lower predation from fish-eating birds. The species that declined the soonest and possibly the fastest was corvina. The corvina of the Salton Sea is a piscivore that is likely mostly dependent on tilapia and secondarily on Gulf croaker.

The Salton Sea is intimately linked to the agricultural industry of the region. As- 
signed as a repository for agricultural wastewater by the State of California, the lake would not exist without inflows from irrigation and agriculture would have to find costlier alternatives for tailwater disposal. Salinity is increasing because of the most important inflows from agriculture are saline and because the lake has no outlet. The salinity of the lake is currently at hypersaline levels [9] and rising at $0.5 \mathrm{~g} \cdot \mathrm{L}^{-1} \cdot \mathrm{y}^{-1}[2]$. As did the marine species, the Salton Sea tilapia will eventually be extirpated permanently if salinity keeps increasing. The salinity problem is further aggravated due to water usage conflicts in southern California. The increase in population growth and water conservation practices in agriculture threaten to diminish inputs to the lake and accelerate the increase in salinity. High salinity, via its effects on reproductive failures, has probably become the major culprit for a decreased fishery. The lack of dissolved oxygen and high sulfide levels in the summer is likely the largest problem adult fish face now. Because of the shallow nature ( $8 \mathrm{~m}$ average depth) of the Salton Sea, water turnover events effected by winds cause water deoxygenation during hot months in large areas of the lake. The high nutrient loading (100 - $200 \mathrm{~N}$ to $1 \mathrm{P}$ ) promote algal blooms, which further deplete surface oxygen and contribute to summer fish die offs [2]. Dissolved oxygen and sulfide concentration may be the major factor driving adult fish mortality. Stress due to the high summer temperature (maximum mean water column of $32.8 \mathrm{C}$ ) may indirectly contribute to die offs by adding a physiological burden on adult fish. Winter low temperature may also cause die offs for tilapia due to this fish only tolerate temperatures above 5 C [19]. Low water temperatures may also lower the tolerance of tilapia to salinity [28], exacerbating the negative effects on winter mortality.

Despite the many environmental extremes for fish in the Salton Sea, safe havens in the lake may also be found. The estuarine areas, especially close to the Alamo and New rivers, are locations where cool freshwater, rich in dissolved oxygen, mixes with the waters of the lake proper [2]. Estuarine areas offer, therefore, refugia from low dissolved oxygen and high temperatures during the summer. Such habitats may prove critical in restoring the lake and reverting the current condition for Salton Sea fish. As salinity keeps increasing in the future, those habitats may become the only area suitable for fish feeding and reproduction.

Detrimental effects on adult fish are compounded by reproductive failures to cause what is probably a non-reversible trend in fish abundances for the marine species at the Salton Sea. Because of degrading environmental conditions, the Salton Sea will soon not be able to support its highly diverse and abundant wildlife. Microbial and phytoplankton diversity in the lake are comparable to that in marine ecosystems. Conversely, zooplankton, benthic invertebrate, and fish diversity is low, which may be early warnings of the effects of salinity on the still partly biodiverse Salton Sea. The diversity of resident and non-resident birds, which are not directly affected by salinity, is high. Over 350 species of birds may be observed in the region and over 75 use the Salton Sea area for reproduction [5] [8] [9]. Many bird species are fish eating and will be directly impacted if the fish population collapses. An increase in salinity negatively affects fish reproduction and increase young fish mortality, possibly during their first year of life. A collapse of the fish population has implications outside of the biological realm. Dimi- 
nished visitation from birdwatchers and an absence of recreational opportunities, especially angling, may negatively impact the economy of the region. Alternatively, keeping the Salton Sea a viable environment for wildlife will very likely boost economic development by adding commercial fishery, ecoturism, or resorts to the existing economic revenue sources of birdwatching and angling.

Of the once abundant species of fish in the Salton Sea, only tilapia has remained, and even rebound, from the very low population levels of the early 2000s. Tilapia is a prolific and hardy fish, that has been known to survive hypersaline environments [29], even to the level of $100 \mathrm{mg} / \mathrm{l}$ [30]. Survival, however, does not imply in reproduction success. If salinities keep increasing, reproduction will certainly stop, also eliminating this species from the lake. Tilapia may now be the only link in the food chain keeping a viable population of birds in the lake and surrounding area. Economically, tilapia are also a sought-after resource. Anglers still flock to the lake in search for that species. If salinity increases remain unabated, the health of the system, economic and ecological, may deteriorate beyond immediate repair.

Questions as to the health of the Salton Sea ecosystem have been posed by the general public based on anecdotal data at best. Statements indicating that the fish population is falling apart due to the lake being a toxic dump contradict the fact that the lake was one of the most productive in the world for fish and that Salton Sea fish are larger at age than conspecifics in many other ecosystems [20]. Salton Sea fish do not only offer recreational opportunities, but also provide safe seafood. Perceptions from the general public that the Salton Sea is toxic dump are weak at best. Fish tissue analyzed for organic contaminants indicate that pesticide accumulation is not a problem at the lake, despite high levels in the tributaries [31]. Water contamination of the Salton Sea proper is minimal [32] and fish contamination low [31] [33]. Low contamination in tissues of the barnacle Balanus balanus, a filter feeder, is further evidence against the myth above. Trace metal concentration in the Salton Sea water is also of no concern for aquatic life. The lack of organic compounds and trace metals is attributed to the low solubility of the compounds in saline solutions [32].

I feel that the fisheries of the Salton Sea may return to historic levels only after restocking of marine species if salinity is brought to acceptable levels for those fish. Tilapia, on the other hand, is the only fish that is capable of repopulating the lake if water quality alone is addressed. If there is a remnant population left of the marine species, they have probably reached a point of no return and would not likely be able to repopulate the lake from the remnant individuals that might still be present. I also feel that tilapia is a key resource for the Salton Sea fisheries. If tilapia recruitment is kept adequate, the lake will be able to support game fish such as corvina and once more become a recreational hotspot in California and the Country. Controlling the salinity of the lake will not only positively influence its fisheries, but also have widespread beneficial repercussions through all components of the lake's biota.

\section{Acknowledgements}

The author is grateful to the California Department of Fish and Game, especially to Mr. 
Jack Crayon, for providing post-2000 data.

\section{References}

[1] Salton Sea Authority (2000) Guide to the Salton Sea Restoration Project Environmental Impact Statement/Environmental Impact Report. Department of the Interior-Bureau of Reclamation.

[2] Watts, J.M., Swan, B.K., Tiffany, M.A. and Hurlbert, S.H. (2001) Thermal, Mixing, and Oxygen Regimes of the Salton Sea, 1997-1999. Hydrobiologia, 466, 159-176. http://dx.doi.org/10.1023/A:1014599719989

[3] Carpelan, L. and Linsley, R. (1961) The Pile Worm, Neanthes succinea. In: Walker, B., Ed., The Ecology of the Salton Sea, California, in Relation to the Sportfishery. California Department of Fish and Game, Bulletin 113, 63-76.

[4] Boyle, R. (1996) Life or Death for the Salton Sea? Smithsonian, 27, 87-97.

[5] Jehl Jr., J.R. (1994.) Changes in Saline and Alkaline Lake Avifaunas in Western North America in the Past 150 Years. Studies in Avian Biology, No. 15, 258-272.

[6] Kaiser, J. (1999) Battle over a Dying Sea. Science, 284, 28-30. http://dx.doi.org/10.1126/science.284.5411.28

[7] Cohn, J. (2000) Saving the Salton Sea. Bioscience, 50, 295-301. http://dx.doi.org/10.1641/0006-3568(2000)050[0295:STSS]2.3.CO;2

[8] Shuford, W.D., Warnock, N., Molina, K.C. and Sturm, K.K. (2002) The Salton Sea as Critical Habitat to Migratory and Resident Waterbirds. Hydrobiologia, 473, 255-274. http://dx.doi.org/10.1023/A:1016566709096

[9] Hurlbert, A., Anderson, T., Sturm, K. and Hurlbert, S. (2007) Fish and Fish-Eating Birds at the Salton Sea: A Century of Boom and Bust. Lake and Reservoir Management, 23, 469-499. http://dx.doi.org/10.1080/07438140709354033

[10] Tiffany, M.A., Swan, B., Watts, J. and Hurlbert, S.H. (2002) Metazooplankton Dynamics of the Salton Sea, 1997-1999. Hydrobiologia, 473, 103-120. http://dx.doi.org/10.1023/A:1016529617757

[11] Blake, W. (1914) The Cahuilla Basin and desert of the Colorado. In: MacDougal, W., Ed., The Salton Sea Carnegie Institute Publication 193: 1-12, Washington.

[12] Hubbs, C. and Miller, R. (1948) The Great Basin with Evidence on Glacial and Post-Glacial Times II. The Zoological Evidence. University of Utah Bulletin, 38, 103-112.

[13] Yohe, R. (1998) Notes on the Late Prehistoric Extension of the Range for the Muskrat (Odatra zibethicus) along the Ancient Shoreline of Lake Cahuilla, Coachella Valley, Riverside County, California. Bulletin of the Southern California Academy of Sciences, 97, 86-88.

[14] Walker, B.W., Whitney, R.R. and Barlow, G.W. (1961) The Fishes of the Salton Sea. In: Walker, B.W., Ed., The Ecology of the Salton Sea, California, in Relation to the Sport Fishery. California Department of Fish and Game, Bulletin 113, 77-91.

[15] Evermann, B. (1916) Fishes of the Salton Sea. Copeia, 34, 61-63. http://dx.doi.org/10.2307/1436917

[16] Dill, W.A. and Cordone, A.J. (1997) History and Status of Introduced Fishes in California, 1871-1996. California Department of Fish and Game, Bulletin 178.

[17] Black, G. (1988) Description of the Salton Sea Sportfishery 1982-83. California Fish and Game Administration Report 88-9.

[18] Costa-Pierce, B. and Doyle, R. (1997) Genetic Identification and Status of Tilapia Regional 
Strains in Southern California. In Costa-Pierce, B.A. and Rakocy, J., Eds., Tilapia Aquaculture in the Americas, 1. The World Aquaculture Society, Baton Rouge, 1-21.

[19] Costa-Pierce, B. and Riedel, R. (2000) Fisheries Ecology of the Tilapias in Subtropical Lakes of the United States. In: Costa-Pierce, B.A. and Rakocy, J., Eds., Tilapia Aquaculture in the Americas, 2. The World Aquaculture Society, Baton Rouge, 1-20.

[20] Riedel, R., Caskey, L. and Costa-Pierce, B.A. (2002) Fish Biology and Fisheries Ecology of the Salton Sea, California. Hydrobiologia, 473, 229-244. http://dx.doi.org/10.1023/A:1016510508187

[21] Caskey, L.L., Riedel, R.R., Costa-Pierce, B., Butler, J. and Hurlbert, S.H. (2005) Population Dynamics, Growth, and Distribution of Tilapia (Oreochromis mossambicus) in the Salton Sea, 1999-2002, with Notes on Orangemouth Corvina (Cynoscion xanthulus) and Bairdiella (Bairdiella icistia). Hydrobiologia, 576, 185-203. http://dx.doi.org/10.1007/s10750-006-0301-2

[22] Lagler, K. (1978) Capture, Sampling and Examination of Fishes. In: Begenal, T., Ed., Methods for Assessing Fish Production in Fresh Waters, Blackwell, Oxford, 7-47.

[23] Lott, J. and Willis, D. (1991) Gill Net Mesh Size Efficiency for Yellow Perch. Prairie Naturalist, 23, 139-144.

[24] Hubert, W. (1996) Passive Capture Techniques. In: Murphy, B.R. and Willis, D.W., Eds., Fisheries Techniques, American Fisheries Society, Bethesda, 157-181.

[25] Kuperman, B.I. and Matey, V.E. (1999) Massive Infestation by Amyloodinium ocellatum (Dinoflagellida) of Fish in a Highly Saline Lake, Salton Sea, California, USA. Diseases of Aquatic Organisms, 39, 65-73. http://dx.doi.org/10.3354/dao039065

[26] Kuperman, B.I., Matey, V.E. and Hurlbert, S.H. (2001) Parasites of Fish from the Salton Sea, California, USA. Hydrobiologia, 466, 195-208. http://dx.doi.org/10.1023/A:1014555904968

[27] Kuperman, B.I., Matey, V.E. and Barlow, S.B. (2002) Flagellate Cryptobia branchalis (Bodonida: Kinetoplastida) Ectoparasite of Tilapia from the Salton Sea. Hydrobiologia, 473, 93102. http://dx.doi.org/10.1023/A:1016577516848

[28] Stickney, R. (1986) Tilapia Tolerance to Saline Waters: A Review. Progressive Fish Culturist, 48, 161-167. http://dx.doi.org/10.1577/1548-8640(1986)48<161:TTOSW >2.0.CO;2

[29] Rodriguez, G., Reyes, J., Gonzalea, A., Delval, C., Cordova, G. and Gonzalez, H. (2015) Effects on Salinity on Three Tilapia (Oreochromis sp.) Strains: Hatching Rate, Length and Yolk Sac Size. International Journal of Aquatic Science, 6, 96-106.

[30] Gonzales, R. (2012) The Physiology of Hyper-Salinity Tolerance in Teleost Fish: A Review. Journal of Comparative Physiology B, 182, 321-329.

http://dx.doi.org/10.1007/s00360-011-0624-9

[31] Riedel, R., Schlenk, D., Frank, D. and Costa-Pierce, B. (2002) Analyses of Organic and Inorganic Contaminants in Salton Sea Fish. Marine Pollution Bulletin, 44, 403-411. http://dx.doi.org/10.1016/S0025-326X(01)00254-5

[32] Holdren, G.C. and Montaño, A. (2002) Chemical and Physical Characteristics of the Salton Sea, California. Hydrobiologia, 473, 1-21. http://dx.doi.org/10.1023/A:1016582128235

[33] Coe, M.F., Surico-Bennett, J., Vicario-Fisher, M., Crane, D., Gerards, R., Gersberg, R.M. and Hurlbert, S.H. (2007) Contaminants in Tilapia from the Salton Sea, California, in Relation to Human Health, Piscivorous Birds and Fish Meal Production. Hydrobiologia, 576, 127-165. http://dx.doi.org/10.1007/s10750-006-0299-5 
Submit or recommend next manuscript to SCIRP and we will provide best service for you:

Accepting pre-submission inquiries through Email, Facebook, LinkedIn, Twitter, etc. A wide selection of journals (inclusive of 9 subjects, more than 200 journals)

Providing 24-hour high-quality service

User-friendly online submission system

Fair and swift peer-review system

Efficient typesetting and proofreading procedure

Display of the result of downloads and visits, as well as the number of cited articles

Maximum dissemination of your research work

Submit your manuscript at: http://papersubmission.scirp.org/

Or contact nr@scirp.org 